\title{
The Role and Position of Veil (Cover) in Promoting Family and Woman's Spiritual Health
}

\author{
Maryam Solgi ${ }^{1}$ \\ Zohrehsadat Nabavi ${ }^{2}$ (D) \\ Maryam Safara ${ }^{3} \Varangle$ \\ ${ }^{1,3}$ Department of Psychology, Women Research Center, Alzahra University, Tehran, Iran \\ Email:m.solgi@alzahra.ac.ir \\ ${ }^{3}$ Email:m.safara@alaahra.ac.ir \\ Department of Islamic Teachings, Payame Noor University, Tehran, Iran \\ Email: z.nabavi89@gmail.com
}

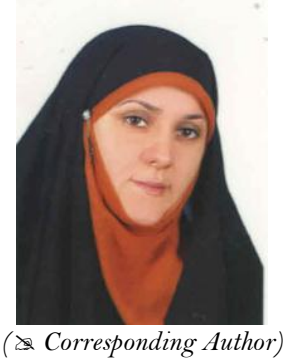

\begin{abstract}
Veil (hijab) is one of the most important elements in the spiritual health of women. This study aimed to investigate the relationship between the veil and spiritual health in women and its impact on the spiritual health of the family, and to explain this issue in the dimension of the health of women and family as well as community by referring to some psychological effects of the veil (hijab). The veil enhances the value of women and above all provides their mental security with protection of human emotions and adherence to moral principles. Veil is responsible for strengthening the family foundation, and guarantees its spiritual health and is as a phenomenon effective in providing family health, which appears as a dynamic and pioneer attribute and saves the family from disintegration. This paper deals with components that consider the veil as a prominent factor in the health of woman and family. The research method used in this study was library method through content analysis.
\end{abstract}

Keywords: Spiritual health, Woman, Family, veil.

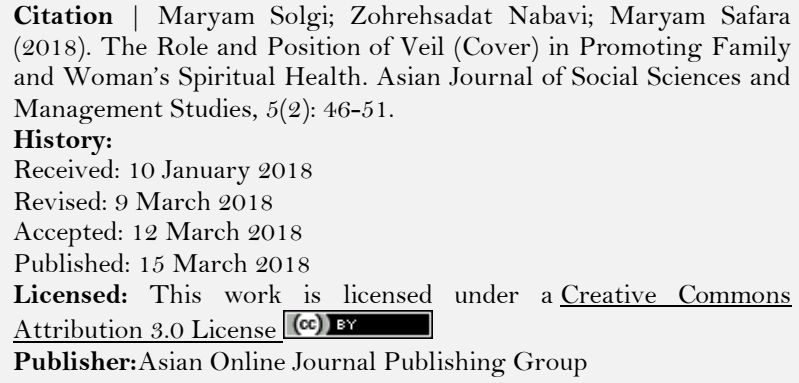

Citation | Maryam Solgi; Zohrehsadat Nabavi; Maryam Safara (2018). The Role and Position of Veil (Cover) in Promoting Family and Woman's Spiritual Health. Asian Journal of Social Sciences and Management Studies, 5(2): 46-51.

History:

Received: 10 January 2018

Revised: 9 March 2018

Accepted: 12 March 2018

Published: 15 March 2018

Licensed: This work is licensed under a Creative Commons

Attribution 3.0 License (cc) E

Publisher:Asian Online Journal Publishing Group

Contribution/Acknowledgement: All authors contributed to the conception and design of the study.

Funding: This study received no specific financial support

Competing Interests: The authors declare that they have no conflict of interests.

Transparency: The authors confirm that the manuscript is an honest, accurate, and transparent account of the study was reported; that no vital features of the study have been omitted; and that any discrepancies from the study as planned have been explained.

Ethical: This study follows all ethical practices during writing.

\section{Contents}

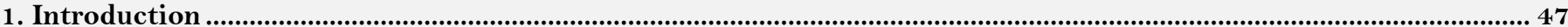

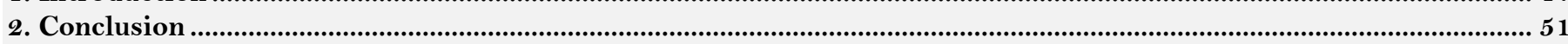

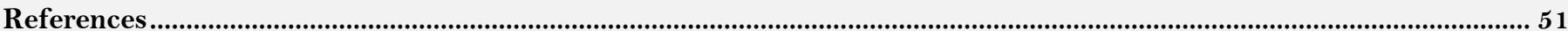




\section{Introduction}

Women as a half of the population of human community play a decisive role in maintaining the society health, because they themselves constitute the half of the society and can affect the other half (the men). They can be the axis of the moral virtues by correct functioning and paying attention to religious and moral orders and recommendations, and lead the society to perfection. In addition, women as mothers play a decisive role in the health of their children. A variety of factors can affect the health of women that one of them that is examined as a special issue is the veil (hijab). Veil can be known as one of the factors affecting the health of women and the community; and due to this issue, God has referred to hijab and chastity in the holy Qur'an completely, clearly and in details as one of the most important and pivotal factors affecting the health of community. Therefore, of the strongest verses of the Holy Quran are verses about veil in which all details have been explained explicitly.

The issue of hijab (covering) that has been acted on based on the nature of the man and woman can have a great impact on the peace of soul and mind of human being. Also, it is the factor of creating security, easiness of life and increasing the respect to woman. In addition, hijab has some effects on family, including strong family ties, strengthening and protecting the family foundations and the enhancement of husband's interest in his wife.

Hijab can have an effective role in marriage and create the feeling of more peace in life. Certainly, the individual's peace in family greatly affects the society, which constitutes individuals, because woman as the spouse and mother plays an important role in family so that the family's health and peace depend on the woman's health and peace.

\subsection{Definition of Spiritual Health}

Today attention to spiritual dimension of health has been considered in many definitions presented for health and some suggestions have been provided for inclusion of spiritual health as one aspect of health in the definition of World Health Organization.

Dealing with the precise conception of spiritual health and defining what the spirituality implies in this case, that is, achieving a signified conception is perhaps the first step to achieve a community with people who are healthy in all dimensions, and this issue, i.e., providing a precise and comprehensive definition of spiritual health is the most important challenge of addressing with this issue.

One of the drawbacks of spiritual health studies until now is their failure to analyze the various aspects of spirituality. Complex and intertwined nature of spirituality and religion has also caused misunderstanding about the equality of these two and consequently the confusion (Carsonn, 1989; Emblen and Halstead, 1993).

Authors have dealt with the spiritual health from different aspects and have presented different definitions so that it can be said that there is no consensus about the definitions of spiritual health.

According to Schooner, spirituality is the experience a meaningful relationship with self, others, the world and the dominant power which is expressed in the form of reactions, narratives and actions (Dehshiri et al., 2008).

Meyer believes that spirituality is constantly searching for meaning and purpose of life, a deep understanding of the value of life, the vastness of the universe, the existing natural forces and personal belief systems. Heinles knows spirituality as an attempt to foster sensitiveness towards the self, others, and non-human creatures, or God or what needed to achieve humanity and a search for achieving perfect humanity (Rastgar, 2010).

Soeken states spirituality as "the existence and experience of interactive connection between human and environment" (Soeken, 1989). Elkins et al. (1998) define spirituality as "a way of being and experiencing that is described by awareness of a transcendental dimension based on certain values in the viewpoint of the self, others, nature and life (Elkins et al., 1998). In this definition, Elkins tries to expand the concept of spirituality to include both religious and non-religious beliefs.

Hungelman et al., in a qualitative study identified the features of spiritual health. In the study, they considered the spiritual health as "a sense of being connected, the coordination between self and others, and the transcendental existence or nature that is achieved through a dynamic and integrated process and leads to identification of the ultimate goal and the meaning of life" (Hungelman et al., 1985).

In this definition, the concept of spiritual health is understood through sensory perception and is used to convey the perceptions and information.

Chapman produces a list of requirements intended for any definition of spiritual health:

1. It should not be considered synonymous to theology and individual responses to personal and complex questions must be avoided;

2. It should be practical and realistic, vast, concentrated and easily transferable;

3. It must be easily recognizable and separable from other areas of health and be applicable to all people and human beings;

4. It must be associated with health and well-being;

5. It must have an appropriate and acceptable scientific basis and validate the study principles and techniques;

6. It must prevent presenting new ideas and concepts in the field of health (Chapman, 1986: quoted in (Fisher, $2010 b)$ ). Bensley by reviewing the whole literature of spiritual health concluded that there was no a general accepted definition of spiritual health (Bensley (1991) quoted in Fisher (2010b)).

At last, he tried to present a combinative definition of spiritual health and based on these definitions he classified this entity as six perspectives:

1. The sense of satisfaction in life;

2. The values and beliefs of the self and society;

3. The wholeness in life;

4. A factor in well-being;

5. A divine power or superior monitoring and control;

6. Spiritual interaction (Fisher, 2010b).

Over the time, other definitions of spiritual health were presented; according to Hawks et al., spiritual health is being connected with others, having meaning and purpose in life and having belief and connection with a superior power (Hawks et al., 1995). 
Reily et al believe that spiritual health is considered as a pivotal philosophy of life and the result of satisfying the need for purpose, meaning, love and forgiveness and "existential health" refers to the efforts to understand the meaning and purpose in life and "religious health" is defined as the satisfaction resulted from the relationship with a superior power or divine power (Reily et al., 1998).

In conclusion of this topic, perhaps the definition of spiritual health by Hungelman et al. (1985) can be considered as the dominant definition. At the same time, in a comprehensive and preventive definition and in drawing the concept of spiritual health, it can be said that the spiritual health is the enjoyment of acceptation sense, positive feeling, ethics, the sense of interactive connection with a divine and superior power, others and the self that is achieved during a cognitive, emotional, interactive, dynamic and coordinated process which is a personal outcome. All those who are trying to explain and promote the idea of spiritual health, especially with Islamic attitude, agree that the definition of spiritual health is too difficult and cannot limit it to a certain field (Marandi and Azizi, 2010). Perhaps it can be said that the main cause of being difficult the definition returns to two main factors. The first factor is the type of the dominant world view, attitude and paradigm that usually there is behind a look and judgment. It is very clear that those who look at human, God, nature, and other supernatural truths and values purely spiritually, materially or as a combination of the two have different views, perception and judgment and naturally when human view, perception or judgment becomes different, the behaviors, actions and attitudes also become different. The second factor that plays an important role and typically depends on the first factor is the lack of agreement about the concepts of words such as spirituality, religion, soul, mind and other related elements. These two factors have caused that the possibility of providing a logical definition of spiritual health is associated with serious difficulty. But in definition of spiritual health in the perspective of Islam, it has been said: "The human being that has a dynamic and evolving relationship with the entire universe consciously is one who is mentally healthy. The most excellent pattern of healthy human beings is divine prophets" (Ahmadi, 2009).

Some Muslim thinkers know spirituality as a set of attributes and actions that create strong, and at the same time, correct and logical attraction and enthusiasm in human being to direct him/her forward in the path to God and the path that is surprisingly popular to the world (Mousavi, 1994). Motahari considers spirituality as an innate sense and intention of human beings towards immaterial things such as science and knowledge, moral goodness, beauty, holiness and worship that are the attributes differentiating humans from other creatures (Motahari, 1993).

According to the above-mentioned definitions, perhaps we can provide a precise and comprehensive definition of spiritual health as follows: "Spiritual health is the existence of a state in the human soul that with the existence of it, a person does not feel any shortage mentally, socially and so on.

\subsection{Veil (Hijab) and its Impact on Women's Spiritual Health}

It is clear that the veil and covering has a great impact on women's mental health. Woman's veil and chastity is like a protective shelter that in the light of it the possibility of keeping human personality of woman from personal and social harms is provided. Veil protects woman from being abused by the lascivious men and from declining her value so that she is only a means for suppression of the lusts. The importance of veil is due to the reason that it is not only the protector of woman's morals and manifestation of her chastity and modesty in the society but also leads to presentation of a correct definition of human position of woman.

The reality is that many problems of the women in the past time were often due to the reason that the human aspect of women was forgotten, and her new problems is because of the reason that her womanly nature and her natural and innate condition, her mission, intrinsic demand and special talents has been intentionally or unintentionally forgotten (Motahari, 1993). Attention to the psychological aspects of veil is very important. No doubt that veil and latency plays an important role in the spiritual health of the woman.

In this paper, the meaning of hijab (veil) is the Islamic covering of Muslim women and the meaning of the Islamic covering of woman, as one of the obligatory provisions of the Islam, is that a woman covers herself when associating with men, and does not show herself off and present her beauties to others. This issue has been clearly mentioned in the verse 59 of Surah-i Ahzab, where God addressing the holy Prophet (SA) says: "O Prophet! Tell your wives, your daughters, and the women of the faithful to draw closely over themselves their chadors [when going out]. That makes it likely for them to be recognized and not be troubled" (Ahzab/59).

And in another verse, God says: "When you ask [the prophet's] womenfolk for something, do so from behind a curtain. That is chaster for your hearts and theirs" (Ahzab/53).

From the above verses clearly understood that hijab (veil) is a necessary issue because it protects the heart from sin and causes its clearness, as well as protects woman from bothering of lascivious men and finally the spiritual health of woman.

Spiritual health is one of the greatest blessings of God and in fact, without realizing this aspect of health, its other aspects, i.e., the mental health, physical health and social health will not be achieved. So here we refer to some effects of veil that influence women's spiritual health as well as their mental health.

\subsubsection{Security}

Security is an essential requirement for the development of the human personality that in the absence of supplying it the growth of personality is disrupted. Women, because of some innate and personality characteristics, are more prone to psychological vulnerability, so they need more security to avoid damages caused by insecurity.

The statistics show that the nudity and sensual adornment of women in the west have caused the arousal and erotomania of some young males and men so that this condition in some cases has caused the reason for attack to and rape of women. Thus, these women do not have security (Rajabi, 2010). Based on Qur'anic verses mentioned above, the women that show themselves off in the public places and cause the arousal of men must expect receiving annoyance from these individuals. In Qumi's interpretation of Qur'an about the verse 59 of Surah-i Ahzab, we read: "Muslim women went the mosque and did their congregation prayer with the Prophet (PBUH). When they went out to say the prayers of down (morning), evening and after, the youth stood on their route and bothered them. At that time, this verse (verse 59 of Ahzab) was revealed that emphasized on women's veil and covering as a protection against the others' harassment (Qumi, 1990). 


\subsubsection{Being Valuable the Woman}

One of the other results of observing veil (hijab) for women is to become more precious to man and therefore, the creation of love that is the most pleasant part of human emotions. Will Durant knows the main need of woman in the marital life as being loved and being paid her the attention by man and in this regards writes: "Woman is alive when she is beloved and attention to her is the basis for her being alive" (Durant, 1990).

If enough attention and love is not paid to women or they are despised, they will be more prone to mental problems and distress than men and will lose their mental health. For this reason, in Islam, attention and love to a woman has been emphasized in three times:

a) When she is a little girl: Parents must love and pay special attention to her at this time;

b) After marriage: At this phase, she should be greatly loved by her husband;

C) When she becomes a mother. At this time, she should be loved and special attention must be paid to her by her children (Al-Hurr-i al-Ameli, 1988; Kuleini, 1988).

An important question that arises here is that in what way can a woman maintain her real value? Martyr (Shahid) Motahhari says: "Keeping the retaining distance between a man and the self by a woman has been a secret tool that woman has used to maintain her position against the man. Islam has encouraged women to use this tool. Islam says that the more a woman moves calmer, and the more dignified and the less show herself off to the men, the more she will be respectful" (Motahari, 1993). In addition, Madam Simone de Beauvoir, the famous French scientist, says: "The young girls like that the men want themselves, not having sexual intercourse with them. Therefore, the men's looks praise them but at the same time bother them. The man's desire is as much as admiration is an insult. If girls, of course, feel that the men look their bodies sexually, they will try to cover themselves. From here, the modesty and shame appears (De Beauvoir, 1981).

\subsubsection{Psycho-Social Growth}

Of the important results of the veil and latency that has a direct impact on women's mental health is psychological maturity and personality of a woman. Monotheistic religions have recommended a way that is one of the most effective ways to increase woman's personality and freedom from dependence to attraction of attention and show-off is latency and covering. Latency for girls is one of the basic needs for mental growth and maturity at the stage that must be met in adolescence.

By covering themselves, except in the family realm, the girls (and women), in fact, teach the others how to keep their looks in order to use their attraction constructively in the realm of the family and strengthen this sacred institution. In fact, this practice (hijab) is an adjustment against the natural demand (of a woman), but is in contrast with the fourth stage of growth that requires attraction and absorption. The latency (veil) of girls is like going to school in a cold winter climate that is naturally associated with the acceptance of suffering and tolerance of pressure. But this is essential for not going to waste the enlightening and constructive forces of girls who are the future women. As the verses related to hijab have referred to it Rouhani (1980).

\subsubsection{Protection of Human Emotions of Women with Hijab}

Being different the emotions and feelings is one of the obvious differences between men and women. Theses emotions play an important and crucial role in human life and this role is important for two reasons: First, it is an important source and the main factor for peace in marital life, and second, it is due to the responsibility and the role of motherhood. By making obligatory the hijab, Islam has determined the best way to maintain and survive the valuable and humane emotions and feelings of a woman.

\subsubsection{Veil (Hijab) and Adherence to the Principles of Human Morality}

One of the most essential human needs to achieve mental health is the ethics and adherence to its principles. Human being can achieve spiritual peace and health when s/he lives in the light of faith and morals. The main condition for adherence to ethics is to avoid falling in the abyss of animal passions. The holy Prophet, Muhammad, $(S A)$ knows the men and women trapped in sexual lust as the largest field of moral decline (Nuri, 1987).

In this regard Imam Ali (AS) also says: "If there was not the women's immodesty and promiscuity, [the faith and morals became so well that no one would disobey God and] God was truly worshiped (Al-Hurr-i al-Ameli, 1988). Therefore, it can be concluded that maintaining ethics and faith in communities and keeping peace and tranquility are significantly related to keeping hijab by women and observing the retaining distance between man and woman. About the role of women in maintaining ethics, Walter says: "The task of women is to edify the men's morals". He adds: "The woman was created in order the tie of prosperity and improvement of creatures to be cont5nued" (Zeravandi, 1990).

\subsubsection{Veil and Modification of the Show-Off Instinct}

Since the latency and veil has an important role in modifying the woman's ostentation and show-off, it is an important factor in preventing a large part of woman's anxiety and mental concerns, which unconsciously leads to providing her spiritual health.

In the book of The Naked Face of Arabian Woman this issue has been stated as well: Beauty does not depends on showing off the projected parts of body and the adornment that hides the inner anxiety and the lack of self-esteem, but more than anything is owned to the thinking power, physical heath and perfection of soul. There were many girls who were captured by mental disorders and various anxieties because of desires to achieve the acceptable signs of beauty and femininity. A girl may imagine that her life and future depends on the size of her nose and the curvature of her eyelash so that even the shortness of her eyelash as much as one millimeter can become a serious problem and a real crisis in her life (Al-Sa'Adawi, 1977).

What makes this problem severer is that the immodest women lose their beauty sooner than others, because the medical science has proven that the nudity of the woman's body members in the cold or warm environment makes imbalanced the hypodermic fats, changes the tenderness, delicacy and smoothness of muscles to the rippling muscles and masculinity them (Paknejad, 1986). 
In addition to what was mentioned above, there are several effects and benefits for hijab in providing the woman's spiritual health that due to limitations of this paper are ignored.

\subsection{The Role of the Veil (Hijab) in the Family Spiritual Health}

Family system is an essential and pivotal institution in society. Basically, the society is created from families; and the importance of this small institution is so great that can be the source of individual and social changes as well as it can contribute to the development or stagnation of human values. For this reason, from the past up to now, the study of the factors affecting on improvement of the position and role of the family has been very important from different aspects. Considering that the prosperity and adversity of an individual begins from her/his family as the first social unit for human being, all divine religions have paid a special attention to this institution as a canon for keeping human dignity and providing his/her physical and mental health and spiritual growth. Islam introduces family as a group consisted of individuals with civil, legal and spiritual rights that its primary core is formed by legal marriage of a man and a woman (Ghaemi, 1984). Reaching the elevated position of humanity and achieving the human transcendental goals, whether individually or socially, depends from one hand on removing all prohibiting factors and on the other hand on opening the chains of captivity. It is here that the veil can be considered as a factor that can be responsible for keeping the mental balance of the human community, strengthening the family foundations and guaranteeing the health of human community, whether man or woman. The appropriate covering of the women of the community, which is referred to as veil (hijab), recovers its real conception as a defensive tool against uncleanness and appears as a dynamic and pioneer phenomenon effective in providing family health and saves the family from faltering.

If hijab is observed in its real meaning in a society and the sexual relations are limited to the family environment, naturally, the youth become more inclined to marriage and the created families will have higher stability. Finally, woman, meanwhile, will receive more benefits because they will enjoy the men's affection and emotional and financial support. About the destructive effects of liberty in relation of man and woman on family, Dr Makkiyeh Mazra says: "One of the effects of sexual promiscuity is that men avoid constituting family, because sexual pleasures are always provided for them and they can easily achieve them, without being exposed to restrictions of constituting family and its problems" (Mazra, 1980).

It is while that Islam wants to keep clean the society from the illegal pleasures and sexual promiscuity by observance of hijab and latency, and allows the people to meet their sexual pleasures in the framework of family and through legal marriage (Wahed, 1984).

Undoubtedly, the family institution will completely grow and flourish through keeping Islamic hijab. In this regard, Shahid (martyr) Motahari says: "The philosophy of being covered and prohibiting the sexual success through someone rather than the legitimate spouse in terms of familial community is that the legitimate spouse of a person is mentally considered as the factor of his/her fortunate, while in the free system of the sexual success, the legal spouse is mentally considered as a person who is a competitor, a distracting individual, and a jailer; consequently the family association is founded based on enmity and hatred" (Motahari, 2000).

The importance of hijab and latency in Islam is due to the reason that it protects the family system from disintegration and makes secure the family members from dangers and harms of sexual promiscuity, while the woman's freedom to do ostentation and show off the feminine beauties has a destructive effect on family mental health and especially the woman herself; because the concept of immodesty is that the woman is allowed to make herself up for any man that the continuation of this behavior causes the woman goes out from the home and becomes vagrant in the streets. We can guess that the least consequence of debauchery in latency and procrastination in relations is the reduced status of the woman in family and the change in sexual taste, so that in the recent decades the change of sexual taste in some communities has led to the expanded moral and sexual deviations in such a way being limited one's sexual relation only to the spouse causes surprising or even despising (Haghshenas, 2008). It is while that the growth of active power of a woman is in the home and family and all talents and the power of increasing impact that a woman can have in the growth and development of the society are flourished in the light of family and household. According to Lambroza, the best period of a woman's life is one when all her mental and physical forces are spent on family and community" (Lambroza, 1990).

While becoming free from the conditions of home and family means the loss of mental peace and security. Home is called the rest place, because it is a place for human relaxation and mental peace. If a woman loses this safe place where she rests and her talents and inner forces are flourished, she will lose her peace and mental health. The anxiety and stress that today has dominated on women in the West is due to the reason that sexual promiscuity and illegal relations have caused they hate from living at home and forget the motherhood duty and instead of it they choose the competitions related to today modern life and sacrifice all spirituals values for it.

No doubt that a community enjoys complete health that the family as a small part of it enjoys complete and sufficient health and strength. Therefore, if we are going to have health and reinforce the foundat5ons of the community, we must mobilize all our forces to stabilize and strengthen the family ties. The existence of the phenomenon of treachery to spouse is the main facto of family disintegration all around the world. It is interesting that in these cases only man is sentenced, while in any treason there has been a woman to deviate a married man by her coquettishness. Since a great part of man's sexual desire is responded by his eyes, the obligation of hijab for a woman against a strange man and keeping the eye by man against a strange woman is one of the best factors that prevent such treasons. Therefore, one of the most important advantages of hijab in the family dimension is to allocate the sexual pleasures to family environment and in the framework of legal marriage. This allocation creates a strong tie between husband and wife and consequently strengthens the family foundation, and in contrast, lack of hijab destroys the foundations of the family. Therefore, of the harmful consequences of non-observance of chastity and hijab (veil) are divorce and disintegration of the family system; it is while that according to Islam, divorce is the most detested legal issue that must be performed in the case of the existence of unsolvable problems. An author has stated the effect of nudity on the destruction and overthrow of the great family tree as follows: "In a society that the nudity is dominant, every man and woman is always comparing, the comparing of what they have with what they do not have; and what burns the root of family is that this comparison adds the fuel to the fire of desire 
in the couple, and especially in the presence of the husband. A woman who has lived twenty or thirty years with her husband and has fought with the difficulties of life and has been a partner for his sadness and joy, obviously, her face gradually loses its beauty and its fall approaches. In such condition when the wife needs the love, affection and loyalty of her husband, suddenly a young woman comes and by her improper covering in the street, market, administration, and school or alley gives the husband the opportunity for comparison; and this comparison becomes an introduction to the destruction of the family foundation and the loss of hope for a woman who has sacrificed her youth (Haddad, 1984).

\section{Conclusion}

Undoubtedly, veil and covering has a very dramatic impact on the women's mental health. However, the purpose of veil (hijab) in its full meaning is to preserve chastity and modesty, and chastity is not merely the apparent latency and includes individual's behavior and action. Chastity and latency for women is like a retaining distance and protection that in the light of it the woman is protected from any torment and humiliation. By making obligatory the veil, Islam does intend to protect woman from lecherous men and her value is not declined so that she only becomes a means to satisfy the carnal desires. From one hand, hijab (veil) strengthens the relations of the family members and establishes intimacy and keeps the family health and consequently the health of society; and the mental peace against the excitations and stresses which can weaken the foundations of individual's personality and the family is one of the elevated goals of Islam in putting forth the issue of hijab that in addition to creating spiritual health for women plays an important role in strengthening the family ties.

\section{References}

Ahmadi, A.A., 2009. Personality psychology from the perspective of islam. 7th Edn., Tehran: Amir Kabir Publications.

Al-Hurr-i al-Ameli, M., 1988. Wasa'l al-Shi'a. Qum: The Institute of Al-i al-Bayt, 20.

Al-Sa'Adawi, N., 1977. The naked face of Arabian woman (translated by Hamid Foroutan and Rahim Moradi). Iran, Tehran: Rooz Behan Publication.

Bensley, R., 1991. Defining spiritual health: A review of the literature. Journal of Health Education, 22(5): 287-290. View at Google Scholar | View at Publisher

Carsonn, B., 1989. Spiritual dimensions of nursing practice. Philadelphia: W.B Saunders.

De Beauvoir, S., 1981. The second gender (translated by Hussein Mehdi). Tehran: Tous Publication.

Dehshiri, G.R., F. Mehrabi, I. Ja'fari and M. Najafi, 2008. The study of the psychometric properties of the spiritual well-being scale among the students. Journal of Psychological Studies, 3(16): 129-145.

Durant, W., 1990. The pleasures of philosophy (translated by Abbas Zaryab). Tehran: Islamic Revolution Organization Training Publication.

Elkins, D.N., J. Heastroml, L.L. Hughes, F.J.A. Lea and C. Saunders, 1998. Toward a humanistic - phenome - nological spirituality. Journal of Humanistic Psychology, 28(4): 5-18.

Emblen, J.D. and L. Halstead, 1993. Spiritual needs and interventions: Comparing the views of patients, nurses and chaplains. Clinical Nurse Specialist, 7(4): 175-182. View at Google Scholar $\mid$ View at Publisher

Fisher, J.W., 2010b. Spiritual health: TTS nature and place in the school curriculum. Thesis.

Ghaemi, A.A., 1984. The family life. Tehran: Parents and Teachers Association (PTA) of Islamic Republic of Iran.

Haddad, A.G.A., 1984. The culture of nudity and cultural nudity. Tehran: Soroush Publication.

Haghshenas, S.J., 2008. The Islamic government and the veil (Hijab). Qum: Office for Women's Studies.

Hawks, S.R., M. Hull, R.L. Thalman and P.M. Richins, 1995. Review of spiritual health: Definition, role, and intervention strategies in health promotion. American Journal of Health Promotion, 9(5): 371-378. View at Google Scholar | View at Publisher

Hungelman, J., L. Kenkel-Rossie and L.M. Syollenwerk, 1985. Spiritual well-being in older adults: Harmonious interconnectedness. Journal of Religion Health, 24(2): 147-153. View at Google Scholar $\mid$ View at Publisher

Kuleini, M., 1988. Al-Kafi. Tehran: Dar al-Kutub al-Islami Press.

Lambroza, G., 1990. The soul of a woman (translated by Hossam Shah-Raeis). Tehran: Danesh Publication.

Marandi, S.A. and F. Azizi, 2010. The status, definition and difficulties of establishing the concept of spiritual health in islamic-iranian community. Journal of Medical Ethics, 4(14): 11-21.

Mazra, M., 1980. The problems of the contemporary women. Mecca: Dar al-Mujtam'a Publications.

Motahari, M., 1993. An introduction to the monotheistic worldview. Iran, Tehran: Sadra Publications.

Motahari, M., 2000. Collected works. Tehran: Sadra Publications, 19.

Mousavi, K.R., 1994. Forty hadithes. Qum: Institute for Compilation and Publication of Imam Khomeini's Works, 13.

Nuri, M.H., 1987. Mustadrak al-Wasael. Lebanon, Beirut: The Institute of Al-i al-Bayt (Lamia), Al-Trath, 14.

Paknejad, S.R., 1986. The first university and the last prophet. Yazd: Shahid Paknejad Cultural Publication.

Qumi, A., 1990. Al-Qumi interpretation of the Holy Qur'an. Lebanon, Beirut: Dar al-Suror Publication, 2.

Rajabi, A., 2010. The veil (Hijab) and its role in mental health. Qum: Imam Khomeini Education and Research Institute.

Rastgar, A.A., 2010. Spirituality in organization with a psychological approach. Iran, Qum: Publication of the University of Religions.

Reily, B.B., R. Perna and D.G. Tate, 1998. Type of spiritual well-being among person with chronic illness: Their relationship to spirituality of life. Archives of Physical Medicine and Rehabilitation, 79(3): 258-264.

Rouhani, S., 1980. Is the veil necessary? The study of the latency issue from the perspective of psychology. Iran, Tehran: Ishraqih Publication.

Soeken, K.L., 1989. Perspectives on research in the spiritual dimension of nursing care in: Carson VB, editor, Spiritual dimension of nursing practice. Philadelphia (PA): Saunders. pp: 354-78.

Wahed, S., 1984. Qurrat al-'Ain (An Introduction to Iranian History on the Subject without veil [hijab]). Iran, Tehran: Rooz Behan Publication.

Zeravandi, A., 1990. The immortal thoughts. Tehran: Me'raji Publication. 